$12-29-2017$

\title{
Inequality in education: experience of eritical Pedagogy and community engagement with Orang Sungai in Paitan, Sabah
}

\author{
Mohd. Suhamimi Mohamad \\ Faculty of Social Science and Humanities, Universiti Kebangsaan Malaysia, msuhaimi@ukm.edu.my \\ Manisah Mohd. Ali \\ Faculty of Social Science and Humanities, Universiti Kebangsaan Malaysia
}

Follow this and additional works at: https://scholarhub.ui.ac.id/ajce

Part of the Social and Behavioral Sciences Commons

\section{Recommended Citation}

Mohamad, Mohd. Suhamimi and Ali, Manisah Mohd. (2017). Inequality in education: experience of eritical Pedagogy and community engagement with Orang Sungai in Paitan, Sabah. ASEAN Journal of Community Engagement, 1(2).

Available at: https://doi.org/10.7454/ajce.v1i2.83

Creative Commons License

(c) (i) ()

This work is licensed under a Creative Commons Attribution-Share Alike 4.0 License.

This Research Article is brought to you for free and open access by the Universitas Indonesia at ASEAN Journal of Community Engagement. It has been accepted for inclusion in ASEAN Journal of Community Engagement. 


\title{
Inequality in Education: Experience of Critical Pedagogy and Community Engagement with Orang Sungai in Paitan, Sabah
}

\author{
Mohd. Suhaimi Mohamada, Manisah Mohd. Alia* \\ aFaculty of Social Sciences and Humanities, Universiti Kebangsaan Malaysia, Bangi, Selangor, Malaysia \\ ${ }^{b}$ Faculty of Education, Universiti Kebangsaan Malaysia, Bangi. Selangor, Malaysia
}

Received: October $20^{\text {th }}, 2017||$ Revised: November $10^{\text {th }} \&$ November 30 $0^{\text {th }}, 2017||$ Accepted: December $12^{\text {th }}, 2017$

\begin{abstract}
The level of literacy among rural communities is still relatively low in Malaysia even though the overall country's literacy rate is considerably high. Literacy rates among indigenous people are lowest in remote communities, especially in Sabah and Sarawak. This is due to reasons like low literacy among the parents and poor school attendance. There have been initiatives attempt to bring literacy level of the indigenous communities to a similar level to that of their non-indigenous peers. Adopting Community Participation Action Research, this study aims to develop and implement a community engagement project through the Literacy Advocacy Program among Orang Sungai who dwells in remote areas in Sabah. Data were gathered through community asset-mapping form on 187 community members and focus group discussion with the community teachers $(n=6)$. The findings of the asset mapping exercise showed that almost $40 \%$ of the Orang Sungai did not attend any formal education. A total of $66 \%$ of household heads have no formal occupation, and the most common profession is farming. Reasons include the inability to read, write or count. The findings also showed that there is a need for community literacy program to empower the community in the development of the nation. Therefore, the Literacy Advocacy Program was planned to use a set of Literacy Advocacy Module. The module consists of 13 sub-modules which require a total of 42hours of adult learning hours. Conducted in the community hall, this program was participated by 21 community members. The community teachers to carry out the program learning activities were appointed by locally trained teachers. Upon completion of the program, participants underwent an oral assessment to measure the effectiveness of the program. The program has shown effective impacts on the adult learning process and the community at large. It has implications on extending the similar format to other marginalised communities in Malaysia.
\end{abstract}

Keywords: education inequality; critical pedagogy; literacy advocacy; adult learning; marginalised community

\section{Introduction}

The issue of development and well-being of communities who live in rural areas are still marginalised from the mainstream development. The indigenous communities such as Orang Sungai in Sabah are still underdeveloped, especially regarding economy, education, culture, environmental sustainability and quality of life (Roszaman, Jalihah \& Dayu 2012). Although the government has established an organisation to develop the rural areas under the Ministry of Rural and Regional Development, the marginalised community in Sabah is still lagging. They still do not have proper electricity, and clean water (treated water) supply, limited telecommunication facilities and most important accessibility to the main road is still considered poor. Besides, the geographical challenges faced by marginalised communities, there is an existing issue of migration from rural areas to cities to improve the living standards of their families through jobs and education (Fatimah Abdullah et al., 2011; Junaenah Sulehan et al., 2013). This phenomenon is common among marginalised communities because they wanted to improve the capacity and opportunities of their families so that they can come out from the cycle of poverty (Mustaffa Omar et al. 2011). For Orang Sungai in Paitan, apart from poverty, the dilemma of maintaining their cultural and ethnic identity to be on par with the majority ethnic

*Correspondence Author: mma@ukm.edu.my 
groups in Sabah like Kadazan, Murut and Bajau are other issues faced by this community (Roszaman, Jalihah \& Dayu, 2012).

Based on the literature, poverty can affect all family members regardless of their gender. It also affects the well-being of families, especially regarding young people educational attainments. The empowerment of marginalised communities should be implemented through the development program with an effective approach to education (Jonsson, 2010; Pimparé, 2005). One way to empower this marginalised community is through Literacy Advocacy Program. Literacy is closely associated with educational elements. Although the two concepts are related, the meaning is quite different regarding practice and effect. Literacy, in general, is a person's capability to read, write and count. Education is a long process to acquire knowledge so that one can conduct reasoning and have a comprehensive understanding. The goal of the planned Literacy Advocacy program is beyond teaching someone to read, count and write but to empower someone to be able to think rationally and logically. An educational goal is beyond the boundaries of literacy where with education the individual can obtain knowledge to a higher level if there is equal opportunity. The education process will continue if the individual is capable and able to deepen their knowledge with enough resources.

In a more specific context, the literacy skills needed to enable community members to deal with the challenges in life, to function effectively as a member of the community and become fundamental to lifelong learning (UNESCO, 2013). A community that has community literacy skills are said to be dynamic. Without literacy skills, community members may face difficulties in improving their quality of life. UNESCO argues that literacy skills are necessary for a Sustainable Development Agenda to be realised in 2030. UNESCO report shows a total of 757 thousand adults including 115 thousand young people are still unable to read or write even simple sentences (UNESCO, 2013). According to the Department of Statistics Malaysia, Malaysian literacy rate aged 15 and above from the year 2000 to 2009 is steadily increasing from 90.1 percent to 92.7 (UNICEF, 2013). In 2015, the literacy rate in Malaysia was considerably high (94.6). However, the level of literacy among rural communities is still relatively low, especially in Sarawak and Sabah.

\section{Theoretical Background}

It is crucial to have a critical pedagogy on a community-based program that suited the local needs and resources. The concept of critical pedagogy was introduced by Paulo Freire to transform adult education into non-traditional and anti-colonial learning and teaching (Mayo, 1999). Freire believed that education could be sensible when learners can make and remake themselves to be able to take responsibility for themselves (Freire, 2004).

This study utilised the Community Participatory Action Research (CPAR) designed by Martin et al. (2012) through community asset mapping which involved the participation of the Orang Sungai community members. Maps of community assets are very useful for the community approval to mobilise the local assets. Besides, the CPAR approach is seen to be adding to the perception and beliefs about local resources and relationships with the marginalised community. The information gathered in this study was deeper and richer through stories, legends and metaphors and used various types of media (traditional and digital).

In this study, the community asset mapping assessment used to identify the needs of Orang Sungai community in Paitan, Sabah. It is also an activity that involves the participation of community members to identify and provide information on local assets that are available in their areas. These include the level of literacy, skills and values that 
each community member held which become the support resources in the community (Burns, Paul \& Paz 2012). It can also be used to identify ways in which community needs can be met. There is a demand to increase the level of literacy among community members, especially for adults. This demand exists because some community members have very minimal literacy level and limited direct exposure to formal schooling. These are mainly dropouts from the education system due to poverty issues. These people are now parents with children attending schools and re facing issues in supporting their children's learning due to their minimal literacy level. Therefore, this study is designed to empower the parents or community members through an adult learning program. Concepts of adult learning highlighted by Knowles (1980), which stressed on the contrast of adult students learning through increased maturity and their unique learning needs, are used in the conceptualization of this study. Also, assumptions on the need for adult learning by Rodrigues (2012) were also included. The six assumptions are (1) adults are responsible for their learning; (2) experience plays a role in adult learning process; (3) there is a willingness to learn; (4) learning orientation is pivoted to the problem; and (6) the internal motivation of adult learners is more powerful than external motivation. It is also hoped that the translational work in the CPAR through this study can change illiterate parents among Orang Sungai to become literate and consequently, these parents will have a better understanding on the importance of education in improving the quality of life among the marginalised community. Therefore, this study addresses the following questions:

a. What is the demography profile of the Orang Sungai community?

b. How is critical pedagogy inculcated in the proposed programme?

c. What are the impacts of the proposed programme on the community?

\section{Methods}

This study applied the community participatory action research. The choice of this research design is mostly based on addressing the practical concerns of the people in the chosen community. Bonilla and Farris (2012) stress that community participatory action research seeks to "change issues that are critical to communities and focuses on engaging community members in research directed at addressing their social concerns". There are five stages involved, namely:

a. Laboratory 1: Preliminary study

i. Seeking approval to conduct the study were made to the local government agency, the community leaders and native chiefs.

ii. Collecting data on community assets through a survey using the community assets mapping technique to record the household profile based on seven types of asset (individual, family, association, physical, economic, cultural, health)

iii. Collecting secondary data through literature, government reports, community records, and others.

b. Laboratory 2: Development of Literacy Advocacy Module

All information obtained from the community assets mapping was used in the development of the Literacy Advocacy Module. The module was developed by a group of researchers from University Kebangsaan Malaysia, officers of the Institute of Development Studies Sabah (IDS), the community teachers and a local research assistant.

c. Laboratory 3: Modification of the Module

The Literacy Advocacy Module underwent modification after going through an evaluation process by the community teachers and appointed module assessors. 
d. Laboratory 4: Implementation of Literacy Advocacy Program

The program was implemented using the Literacy Advocacy Module on 21 community members who volunteered in the program. A total of 42 learning hours was used. The program took place in the community hall.

e. Laboratory 5: Evaluation and Dissemination of Literacy Advocacy Program Outcome

The session involved in assessing participants' performance on the modules. A focus group discussion was conducted with the community teachers $(n=6)$ to gather their feedback on the implementation of the programme. The outcome of the program was shared in a special dialogue session with local government and non-governmental agencies.

Data from the asset mapping activity in Laboratory 1 were analysed descriptively using percentages. The activities in Laboratory 2 to laboratory five are presented in the results and discussion section. Data from the focus group discussion were analysed verbatim and presented in the discussion.

The targeted area in this study is Kampung Abuan, in the interior of Lingkabau District, Sandakan in the state of Sabah. Kampung Abuan is located approximately 65 kilometres from Sandakan and is home to Orang Sungai.

The project is carried out together with the Institute of Development Studies Sabah (IDS). It was started in 2013 in Kampung Abuan with the objective to improve the living conditions through the community education program. There are 17 villages located along the Lingkabau River. It has two primary schools, Sekolah Kebangsaan Lingkabau and Sekolah Kebangsaan Abuan. In 2010, only 38 students completed their primary education in both schools. However, only ten students (26\%) continued their studies to the secondary school in the nearby town. The number of children dropping out of school was relatively high (74\%). The literacy level of the targeted community is also rather low. Children between the age of 6 to 12 are actively learning in the community's school, and those aged 13 to 25 have had some basic education. This gap in the latter group shown there is little access to continue their education at a much higher level. Factors like poverty, distance and legal documents have hampered such access. Also, illiteracy issues among parents also contribute to their children not attending secondary schools. This study will put effort into empowering the older members of Orang Sungai's community through the Advocacy Literacy Programme. On the other hand, it is hoped that parents would be the role models to their school-age children in increasing the awareness of the importance of education.

\section{Result and Discussion}

\subsection{Demography profile of Orang Sungai Community}

Table 1 shows the descriptive results of asset mapping activity in the study. Based on gender, the majority of Orang Sungai were female $53.5 \%$ compared to $46.5 \%$ male. Regarding religious affiliation, there were 50.8\% Christian, 43.9\% Pagan and only 5.3\% Muslims. Data showed that 113 Orang Sungai who participated in this study are single and the remaining 73 people are married. Also, 49.7\% community members are children aged between 2 months to 17 years old, followed by the age group of 18 to 30 years and the lowest in the age group 61 to 80 years a total of $6(3.2 \%)$ people. Most respondents had considerably low education level, as $43.9 \%$ respondents were primary school graduates and only $16.6 \%$ went to secondary school, while the remaining $39.6 \%$ did not attend school. 
Table 1. Asset Mapping Participant's Demography

\begin{tabular}{|c|c|c|c|}
\hline $\begin{array}{l}\text { Demographic } \\
\text { factors }\end{array}$ & Category & $\begin{array}{l}\text { Frequency } \\
\text { (n) }\end{array}$ & Percentage (\%) \\
\hline Gender & $\begin{array}{l}\text { Male } \\
\text { Female }\end{array}$ & $\begin{array}{l}87 \\
100\end{array}$ & $\begin{array}{l}46.5 \\
53.5\end{array}$ \\
\hline Age & $\begin{array}{l}\text { Two months }-17 \text { years } \\
18-30 \text { years } \\
31-40 \text { years } \\
41-50 \text { years } \\
51-60 \text { years } \\
61-70 \text { years } \\
71-80 \text { years }\end{array}$ & $\begin{array}{l}93 \\
43 \\
21 \\
10 \\
14 \\
3 \\
3\end{array}$ & $\begin{array}{l}49.7 \\
23.1 \\
11.2 \\
5.3 \\
7.5 \\
1.6 \\
1.6\end{array}$ \\
\hline Ethnicity & Orang Sungai & 187 & 100.0 \\
\hline Religion & $\begin{array}{l}\text { Islam } \\
\text { Christian } \\
\text { Pagan }\end{array}$ & $\begin{array}{l}10 \\
95 \\
82\end{array}$ & $\begin{array}{l}5.3 \\
50.8 \\
43.9\end{array}$ \\
\hline Marital Status & $\begin{array}{l}\text { Single } \\
\text { Married } \\
\text { Divorced }\end{array}$ & $\begin{array}{l}113 \\
73 \\
1\end{array}$ & $\begin{array}{l}60.4 \\
39.1 \\
0.5\end{array}$ \\
\hline $\begin{array}{l}\text { Level of } \\
\text { Education }\end{array}$ & $\begin{array}{l}\text { None } \\
\text { Primary School } \\
\text { Secondary School }\end{array}$ & $\begin{array}{l}74 \\
82 \\
31\end{array}$ & $\begin{array}{l}39.6 \\
43.9 \\
16.5\end{array}$ \\
\hline
\end{tabular}

$N=187$

A closer look at the level of education of 38 heads of family in the community (Table 2) found that they mostly have not completed or undergone primary education $(18,47.4 \%)$. Thirteen (34.2\%) completed primary education, and a small number completed their secondary education $(7,18.4 \%)$. As for the spouses' level of education, it is found that the majority have not attended or completed primary education $(29,68.5 \%)$. While there is an equal distribution for those who completed primary education (5, 13.2\%) and secondary education $(5,13.2 \%)$. These findings show the discrepancy in education the community.

Table 2. Level of Education of Heads of family and their Spouse

\begin{tabular}{lll}
\hline Level of Education & $\begin{array}{l}\text { Head of Family } \\
(\mathrm{n}=38)\end{array}$ & $\begin{array}{l}\text { Spouse } \\
(\mathrm{n}=39)\end{array}$ \\
\hline $\begin{array}{l}\text { No or not completed } \\
\text { primary education }\end{array}$ & $18(47.4 \%)$ & $29(74.4 \%)$ \\
$\begin{array}{c}\text { Completed } \\
\text { Primary Education }\end{array}$ & $13(34.2 \%)$ & $5(12.8 \%)$ \\
& & \\
$\begin{array}{c}\text { Completed } \\
\text { Secondary Education }\end{array}$ & $7(18.4 \%)$ & $5(12.8 \%)$ \\
\hline
\end{tabular}


Both table 1 and table 2 present the scenario where accessing to quality education has had implicated the community. UNESCO (2012) explains cultural, and community structural factors created barriers to the said scenario. Thus, reducing the opportunities for community members to access to quality education. An alternative approach would be by adopting an approach to empower community members to gain such opportunity through the Literacy Advocacy Program.

\subsection{Literacy Advocacy Approach as Critical Pedagogy}

Literacy Advocacy Program conducted with the involvement of the collaboration of researchers, research partners, university students, teachers and local community members. The community asset mapping results showed the need for improvement of basic literacy skills and community members. This issue exists due to a lack of skills that can affect the local transformation agenda. One of the reasons for the increase in the need for literacy skills is the significant number of community members who have dropped out of formal education either at the primary or secondary levels. This situation leads to their lack of necessary knowledge and skills to find a job. The program identified target groups which are suitable for this program, namely the youth group with limited literacy skills, housewives, and other adults who want to improve their literacy skills.

Learning materials for Literacy Advocacy Program were developed in the form of Literacy Advocacy Module by a group of researchers together with research partners from IDS, and community teachers in a series of community workshops. The Literacy Advocacy module adopts the concept of andragogy, aiming to provide a path of learning and self-improvement (Burns, Paul \& Paz, 2012) to community members who fall behind in the mainstream education system. This module attempts to advocate community members with reading, writing and basic numeracy skills. A total of 13 modules covering three sub-modules on basic literacy skills and numeracy, five sub-modules on self and family, and five sub-modules on the community. The specific modules are listed in Table 3.

Table 3. Items in Literacy Advocacy Module

\begin{tabular}{cc}
\hline Module and submodules & Title \\
\hline Basic Literacy Skills & \\
\hline Module 1 & Recognition of Alphabets \\
Module 2 & Numbers \\
Module 3 & Aramaiti Belajar (Lets study) \\
\hline Self and Family & Myself \\
\hline Module 4 & My Family \\
Module 5 & My House \\
Module 6 & My Village and Culture \\
Module 7 & My Hobby \\
Module 8 & \\
\hline The Community & Economy \\
Module 9 & Today's Recipe \\
Module 10 & Healthcare \\
Module 11 & Let's Sing \\
Module 12 & Mongalai Toko (Lets Dance) \\
Module 13
\end{tabular}


The development and contents of the modules considered the context of the community and their environment. This is done with the aim to aid community members' understanding and raise their enthusiasm for learning. As stressed by Vanitha et al. (2014), the use of aspects of everyday life and experience of indigenous groups should be considered in the development of learning materials for the group. Similarly, Knowles et al. (2005) argue that adults will be facilitated to learn faster if there is a connection between learning and their daily activities. To address this, both Modules 3 and 13 have titles in the local language of the community.

Kampung Abuan's community hall was chosen as the location of the class due to the easy access for the community members. Given the selected location has no necessary classroom facilities, the researchers provided some basic tools for the teaching and learning process, such as tables and chairs as well as stationaries. Also, refreshments were provided after class. The community members who signed up for the program were supplied with a set of learning accessories in the form of a bag, stationaries, notebook, exercise book and worksheet.

Initially, there were only seven community members attended the class. However, the number of enrolment increased to 21 community members towards the middle of the program. The increase in the number of members was encouraging because of the informal and flexible approach adopted by the program. Also, the acceptance of the presence of other community members who are not registered for the program also contributed to the increase in the number of students. They were children or siblings or friends of the program's participants. Community teachers initiated some learning activities to these additional informal participants so that they can equally benefit and consequently expected to be motivated to learn.

The Literacy Advocacy Program was carried out in 42 hours within 26 days. Three teachers from Sekolah Kebangsaan Abuan, a government primary school, located within the community were appointed as community teachers to teach the specially developed Literacy Advocacy Module. These teachers have attended sessions on andragogy learning workshops and participated in the module development workshops. The idea to appoint community teachers came about in understanding the importance of teachers who are non-community members to be part of the local community where the school is located. In this way, teachers will understand better the community's cultural knowledge and at the same time enabling them to inculcate current pedagogical approaches in implementing the program (Giles, 2010).

A community facilitator was appointed as the secretariat for the activities of the program. He also acted as the mediator between community teachers, community members and the research group and helped ensure the learning needs of the participants were met. The completion of the program was held in a special closing event where local community leaders and officers of government agencies were invited. This event was held not only for the participants but also for other community members. During the event, the research group carried out some community activities such as health check-up and birth registration with the support of related government agencies. In doing so, initiatives to increase the quality of life of the community members were included and had contributed an added value to the implementation of the Literacy Advocacy Program.

\subsection{Community Engagement Impacts}

The implementation of the Literacy Advocacy Program has an impact on the community. Specifically, this impact involves four main groups: the community adult 
learners, the community, the community teachers and the group of researchers. For the community group, the main impact is the identification of the key issues in the community through community asset mapping activities. The impact of this program to adult learners are in the form of increased mastery of basic literacy in reading, writing and arithmetic. The literacy module which has thematic learning items focused on community leisure activities has brought about on an improved positive concept of lifelong learning among the participants. They expressed a desire to participate again if there is a new program related to self-improvement and showed appreciation to understand science as a catalyst for the advancement of self and community. Also, their increased self-esteem is shown significantly where they believe they could be better people.

The community members were empowered through the transfer of knowledge by researchers, public university students who acted as research enumerators and community teachers. In addition to minimizing the gap in literacy skills among community members, this program has been instrumental in providing a solution regarding identity cards registration issues and increasing awareness of community members' health issues. As stressed by Westhorp et al. (2014), it is interesting to find that there is a linkage between "community-accountability and empowerment interventions" and low literacy levels among community members.

As implementers, the community teachers expressed the view that the Literacy Advocacy Program has a positive impact on the development of marginalized communities. An analysis of the focus group discussion showed that there is a reduction of the gap between teacher socialization and members of the community. The involvement of community teachers in the current study strengthened the role of teachers as agents of change in their communities. The teachers were also able to innovate and creatively apply various teaching methodologies for participants with diverse backgrounds. Also, application of the inclusive and friendly learning environment concept in the implementation of the programme provided a new perspective to learning for the community members; that learning is not confined to the formal classroom context and that the learners vary in backgrounds and abilities (Zalizan et al., 2011).

As for the researchers, the chance for community-based studies has brought about a deeper understanding of the importance of community engagement and realizing transformational community agenda. The collaboration with the local development agency has created new understanding on the importance of key partner's role in mobilising the local development agenda. On a bigger scale, this programme has created a stronger foundation in enabling the university-community-interagency partnership to develop positively towards engaging key partners and establishing "cross-cutting linkages" (Singh, 2017) in minimising the gaps to access quality education for the targeted community. Such partnership will help realise one of the six strategic thrusts in the Eleventh Malaysia Plan 2016-2020 which is to "enhance inclusiveness towards an equitable society to ensure all Malaysians benefit from economic growth regardless of gender, ethnicity, socio-economic status, or geographic location" (Economic Planning Unit, 2017).

\section{Conclusion}

Literacy Advocacy Program is a community product that strengthened the collaboration and cooperation among university researchers, government officials, teachers and community members in resolving issues in the local communities. The study has some limitations regarding access to the community site and communication system due to geographical factors. Thus, support and assistance from all parties are pertinent 
in mobilizing activities and minimizing logistical challenges for any community programmes. On a micro level, the critical pedagogy adopted in implementing the program has enabled the community members to engage in the programme's activities and promoted lifelong education. The programme's objectives have helped in realizing social change among the community members who called for more community empowerment programmes. This program can be replicated on other marginal communities as part of the efforts for the transformation of a community. Positive participation in the program by various parties has shown the degree of robustness of the planning and execution as well as their full commitment to the success of this programme.

\section{Acknowledgements}

The authors would like to acknowledge their sincere appreciation to the Economic Transformation Program research grant under Project Code: ETP-2013-055 which provide the opportunity to carry out this important mission in advocating literacy among the rural Orang Sungai in Paitan, Sabah.

\section{References}

Bonilla, T. \& Farris, T. (2012). A short guide to community based participatory action research. Retrieved on 18 July 2017 from https://hc-v6static.s3.amazonaws.com/media/resources/tmp/cbpar.pdf.

Burns, J. C., Paul, D.P., \& Paz, S.R. (2012). Advancement project. Retrieved on 27 Mac 2016 from http://communityscience.com/knowledge4equity/AssetMappingToolkit.pdf:

Economic Planning Unit. (2017). Malaysia sustainable development goals voluntary National review 2017. Retrieved on 12 December 2017 from https://sustainabledevelopment.un.org/content/documents/15881Malaysia.pdf

Fatimah Abdullah, Mohd Suhaimi Mohamad \& Siti Hajar Abu Bakar. (2011). Cabaran penjagaan tak formal di Malaysia: Satu tinjauan. Seminar Internasional Serumpun Melayu 2011: Pembangunan, Psikologi dan Masalah Sosial; Fakultas Ilmu Budaya Universitas Hasanuddin, Makassar.

Freire, P. (2004). Pedagogy of indignation. London: Routledge.

Giles, W. (2010). Teacher education in a remote community: Learning on the job., AsiaPacific Journal of Cooperative Education,11(3), 57.

Jonsson J. H. (2010). Beyond empowerment: Changing local communities. International Social Work, 53(3): 393-406.

Junaenah Sulehan, Noor Rahamah Abu Bakar, Abd. Hair Awang, Mohd Yusof Abdullah \& Ong Puay Liu. (2013). Development at the margins: Livelihood and sustainability of communities at Malaysia-Indonesia borders. Sociologijaiprostor, 197 (3), 547-562. 
Knowles, M. (1980). The modern practice of adult education, revised and updated. Englewood Cliffs: Prentice Hall Regents.

Knowles, M., Holton, E., \& Swanson, R. (2005). The adult learner: The definitive classic in adult education and human resource development. 6th edition. Amsterdam: Elsevier.

Martin, M., Peters, B. \& Corbett, J. (2012). Participatory asset mapping in the Lake Victoria Basin of Kenya, URISA. Journal of the Urban \& Regional Information Systems Association, 24 (2), 45-55.

Mayo, P. (1999). Gramsci, Freire, and adult education: Possibilities for transformative action. London: Zed Books.

Mustaffa Omar, Radzi M. M., Selamat M. N., Manaf A. A., Shamsudin M., Saim N. J. (2011). Faktor penentu dan implikasi fenomena depopulasi komuniti pulau kecil di sekitar Mersing. Journal of Tropical Marine Ecosystem, 1, 22-34.

Pimparé, S. (2005). Developing learning communities: Beyond empowerment. Paris: UNESCO.

Rodrigues, K. (2012). It does matter how we teach maths. Journal of Adult Education, 41(1), 29-33.

Roszaman Hussin, Jalilah Md Shah \& Dayu Sansalu. (2012). Orang Sungai. Kuala Lumpur: Institut Terjemahan dan Buku Malaysia.

Singh, W. (2017). Gauging the impact of community university engagement initiatives in India. ASEAN Journal of Community Engagement., 1(1), 1-16.

UNESCO. (2012). Removing gender barriers to literacy for women and girls in Asia and the Pacific. Retrieved on 16 Mac 2015 from http://unesdoc.unesco.org/images/0021/002175/217543e.pdf.

UNESCO. (2013). Adult and youth. Literacy. Retrieved on 16 Mac 2015 from http://www.uis.unesco.org/literacy/Documents/fs26-2013-literacy-en.pdf.

UNICEF. (2013). Malaysia Statistic, Malaysian literacy rate. Retrieved on 10 January 2017 from https://www.unicef.org/infobycountry/malaysia_statistics

Vanitha, T., Saedah Siraj \& Norlidah Alias. (2014). Development of a responsive literacy pedagogy incorporating technology for the indigenous learners in Malaysia. The Turkish Online Journal of Educational Technology, 13 (2), 44-53.

Westhorp, G., Walker, B., Rogers, P., Overbeeke, N., Ball, D., \& Brice, G. (2014). Enhancing community accountability, empowerment and education outcomes in low and middle-income countries: A realist review. London: EPPI-Centre, Social Science Research Unit, Institute of Education, University of London. Retrieved on 10 January 2017 from https://assets.publishing.service.gov.uk 
Zalizan Mohd. Jelas, Manisah Mohd. Ali, Norshidah Mohamad Salleh \& Nor Aniza Ahmad (2011). Kit alat PIMP. Menerima kepelbagaian: Mewujudkan persekitaran inklusif mesra pembelajaran (Terj.) Bangkok: UNESCO/ Bangi: Universiti Kebangsaan Malaysia. 